\title{
ADVERTISING AS A PLATFORM FOR LANGUAGE GAME
}

\section{PUBLICIDADE COMO PLATAFORMA PARAJOGO DE LÍNGUAS}

\section{LA PUBLICIDAD COMO PLATAFORMA PARAJUEGOS DE IDIOMAS}

\author{
Chen NIANZU ${ }^{1}$ \\ Juliya Victorovna AGEEVA ${ }^{2}$ \\ $\mathrm{Li} \mathrm{YI}^{3}$
}

\begin{abstract}
The present study is devoted to the language game as a widespread advertising phenomenon. With reference to contextual analysis of language games in advertisements, the article considers the achievements of the main advertising goals (to attract potential consumers and influence their buying behavior) by virtue of various creative language means. The article discusses and analyzes different types of language games based on phonetics, lexical and grammatical means of the Russian language. Cases of language game with the use of onomatopoeia, homonyms and nonce words are emphasized. The specific features of the linguistic phenomenon in advertising are illustrated with appropriate examples. Reportedly, advertising makes possible the language game and, in certain cases, is an ideal environment for its implementation. Considering the language game as an integral part of the advertising discourse, the authors of the article draw conclusions about the similarity of the communicative goal in the language game and advertising. Apart from contributing to the theory of advertising from the standpoint of modern linguistics, and to the development of the language game theory, the results of the study explore creative possibilities of language, including in advertising.
\end{abstract}

KEYWORDS: Advertisements. Language game. Onomatopoeia. Homonyms. Nonce words.

RESUMO: O presente estudo se dedica ao jogo de linguagem como um fenômeno publicitário de ampla difusão. Com referência à análise contextual do jogo de linguagem na publicidade, o artigo considera o alcance dos principais objetivos da publicidade (atrair consumidores potenciais e influenciar seu comportamento de compra) por meio de vários meios da linguagem criativa. $O$ artigo discute $e$ analisa diferentes tipos de jogos de linguagem baseados em meios fonéticos, lexicais e gramaticais da lingua russa. Enfatizam-se os casos do jogo de linguagem com o uso de onomatopeias, homônimos e palavras nonce. As características específicas do fenômeno linguístico na publicidade são ilustradas com exemplos apropriados. Conhecidamente, a publicidade possibilita o jogo de linguagem e, em certos casos, é ambiente ideal para sua implementação. Considerando o jogo de linguagem

${ }^{1}$ Kazan Federal University (KPFU), Kazan - Russia. Assistant at the Department of Russian as a Foreign Language, Institute of Philology and Intercultural Communication. ORCID: https://orcid.org/0000-0001-79213823. E-mail: chennianzu0325@yandex.ru

${ }^{2}$ Kazan Federal University (KPFU), Kazan - Russia. Professor of the Department of Russian as a Foreign Language, Institute of Philology and Intercultural Communication. Doctorate in Philology Sciences. ORCID: https://orcid.org/0000-0001-7903-3574.E-mail: jageeva@yandex.ru

${ }^{3}$ Xi' an International Studies University (XISU), Xi'an - China. Assistant at the Institute of Russian Language. Doctorate in Philology Sciences. ORCID: https://orcid.org/0000-0002-2637-4268. E-mail: liyiyishu9@1126.com 
como parte integrante do discurso publicitário, os autores do artigo tiram conclusões sobre a semelhança do objetivo comunicativo no jogo de linguagem e na publicidade. Além da contribuição para a teoria da publicidade do ponto de vista da linguística moderna, e para o desenvolvimento da teoria dos jogos de linguagem, os resultados do estudo exploram as possibilidades criativas da linguagem, incluídos na publicidade.

PALAVRAS-CHAVE: Anúncios. Jogo de linguagem. Onomatopeia. Homônimos. Palavras inéditas.

RESUMEN: El presente estudio está dedicado a un juego de lenguaje como fenómeno publicitario de amplia difusión. Con referencia al análisis contextual del juego del lenguaje en la publicidad, el artículo considera la consecución de los principales objetivos publicitarios (atraer consumidores potenciales e influir en su comportamiento de compra) en virtud de diversos medios de lenguaje creativo. El artículo discute y analiza diferentes tipos de juegos de lenguaje basados en medios fonéticos, léxicos y gramaticales del idioma ruso. Se enfatizan casos del juego del lenguaje con el uso de onomatopeyas, homónimos y palabras nonce. Las características específicas del fenómeno lingüistico en la publicidad se ilustran con ejemplos apropiados. Según se informa, la publicidad hace posible el juego del lenguaje $y$, en ciertos casos, es un entorno ideal para su implementación. Considerando el juego del lenguaje como parte integral del discurso publicitario, los autores del artículo extraen conclusiones sobre la similitud del objetivo comunicativo en el juego del lenguaje y la publicidad. Aparte de la contribución a la teoría de la publicidad desde el punto de vista de la lingüistica moderna, por un lado, y al desarrollo de la teoría de los juegos del lenguaje, por otro lado, los resultados del estudio podrían explorar fructíferamente las posibilidades creativas del lenguaje, incluyendo en publicidad.

PALABRAS CLAVE: Anúncios. Juego de lenguaje. Onomatopeya. Homónimos. Nonce words.

\section{Introduction}

Advertising has become an integral part of popular culture and a market economy over the past decades. It is strongly positioned in information, social and cultural spheres; it activates the demand of customers and influences their leisure based on stereotypes of consumer behavior. In addition, advertisements can act as a trade engine and an impetus for the development of speech activity. The influence of advertising is not limited to the consumer market. It concerns cultural, social and political life of society, functioning and developing language and its system. Thereby, it is essential to continue with linguistic studies of advertisements.

Advertising is a significant part of the mass culture discourse. Linguists address the concept of discourse. Therefore, recent studies evaluate linguistic and non-linguistic characteristics of different discourses with special attention to political discourse (ZHAO; 
YALING; SHULEZHKOVA; HARRY WALTER; BOCHINA; KOSTINA， 2017; GIMRANOVA; KOLOSOVA; SEMUSHINA， 2018; YAPPAROVA; BOCHINA; SADYKOVA, 2016; YAPPAROVA; AGEEVA; AGMANOVA, 2017). Internet discourse (MIFTAKHOVA; BOCHINA; SERGEEVA, 2017), and business discourse (AGEEVA YU, 2018). For instance, Yu.V.Ageeva refers to the theory of a new Russian business discourse with focus on communicative tactics in different business areas from a lexical-semantic perspective (AGEEVA, 2017).

Summarizing general features of the discourse, N. N. Mikhailov concluded that advertising is "an independent type of discourse with the ability to interact with other discourse types" (MIKHAYLOV, 2011, p. 32). Likewise other texts, advertisements utilize various language means, including creative ones. One of the main creative strategies is a language game. The term language game was first coined in 1945 by the Austrian philosopher, representative of the analytic tradition Ludwig Wittgenstein in Philosophical Investigations. According to his concept, "the process of using words in a language can be represented as one of the games children play to learn their native language. I will call these games "language games" and sometimes talk about some primitive language as a language game" (AGEEVA, 2017, p. 83). In his writings, the language game is also defined as a special manipulating technique.

Firstly introduced in Russian linguistics by E. A. Zemskaya, M. V. Kitaygorodskaya and N. N. Rozanova in the corresponding book, the notion of language game is interpreted as a linguistic phenomenon "when a speaker plays with the form of speech, a free attitude to the form of speech receives an aesthetic task, even the most modest one. It could be a simple joke, or more or less good joke, a pun, different types of tropes (comparisons, metaphors, periphrases, etc.)" (ZEMSKAYA; KITAYGORODSKAYA; ROZANOVA, 1983, p. 175).

The aim of the article is to study the language game in advertising discourse to prove the efficiency of this linguistic phenomenon in accomplishing the main communicative goal of the advertisement that is to attract customers.

\section{Methods}

The authors turn to the following research methods: analysis and synthesis of theoretical and empirical material; deduction and induction; descriptive (generalization and classification of the analyzed material) and interpretive methods which are used in the selection of advertisements. 


\section{Results and discussion}

Considering the theory provided by the aforementioned researchers, it can be argued that the language game, firstly, is built on the basis of certain language standards. Secondly, the game is a creative activity: notably, one cannot constantly stick to stereotypes in creativity. Furthermore, L. Wittgenstein claims that "language games change over time," and when it happens, "concepts and the meanings of words" are modified (AGEEVA, 2017, p. 370). The author observes that people can gradually develop different ways of expressing themselves and provide a new meaning to previous language habits. Emerging advanced technologies continuously accelerate the process of language renewal in an incredible manner. For example, current Internet slang has high impact on the evolution of language; it has a special effect on the language of youth, in particular, on the emergence of new language forms (GUZAEROVA; BASTRIKOV, 2019). One cannot but agree that the language game enriches the language to some extent. Moreover, it could be declared that the language game expands language capabilities as an example of the real and flexible use of language units. It makes possible to go beyond the strict standards of speech while the meaning of a particular language game can be understood only in a specific communicative context.

A sufficient theoretical underpinning to advertising has already been provided by scientists in various fields. The primary advertising objective is to attract attention in order to influence consumer behavior. It should be noted that the language game has a similar task in arousing the interest of the reader by creating a comic effect. It is logical that advertising and the tactics of the language game, to some extent, coincide in their purpose. Many researchers study the connection between the language game and advertising, including A.A. Schurina who emphasizes incorporation of entertaining and influencing functions. Moreover, the language game is characterized by the ability to "please readers emotionally, amuse and cheer them up. Using the language game, the advertiser intends not only to lure customers but also to make buying a certain product, to spark interest" (SCHURINA; YU, 2006, p. 85). S. V. Ilyasova refers to the importance of implementing unconventional language means in advertising: "Advertising is a combination of different arts, not least of which psychology and linguistics are. High competition forces advertisers to create unique and attractive advertisements" (ILYASOVA; AMIRI, 2009, p. 35).

The linguistic means used in language games are diverse. The classification of language games is presented by V. Z. Sannikov (LEBEDEVA, 2014). E. A. Zemskaya 
(ZEMSKAYA; KITAYGORODSKAYA; ROZANOVA, 1983). S. V. Ilyasova (ILYASOVA; AMIRI, 2009, p. 35). T. A. Gridina (GRIDINA, 1996). For example, V. Z. Sannikov provides in-depth description of language games in a wide range of literary works; S.V. Ilyasova classifies language games in media texts.

Further, we introduce examples that illustrate the most commonly used tactics of the language game in production of creative advertisements.

\section{At the level of phonetics}

1) Onomatopoeia. The Linguistic Encyclopedic Dictionary defines onomatopoeia as "a natural involuntary connection between the phonemes of a word and the acoustic attribute of denotation (motive) underlying the nomination" (YARTSEVA, 1990, p. 165). Onomatopoeia is regularly used in advertisements because the sounds of nature (birds singing, the murmur of a stream, etc.) typically draw the attention of both curious children and adults. This ability is consistent with the primary purpose of advertising, namely, to capture the attention of clients. In addition, onomatopoeia evokes associations with the sounds of certain animals. One of the examples is the name of the well-known cat food company Meow Mix (meowmix.com). The sound meow, similar to that made by cats, is used in order to grab attention and evoke an association with this animal.

Another famous advertisement for cat food "Whiskas" is: «Ваша киска купила бы Whiskas» ("Cats would buy Whiskas") (www.whiskas.ru). Two consonants in the name of the Whiskas brand evoke associations with the sounds kis-kis-kis by which Russians call a cat. Subconsciously, it establishes a connection between the product and animals whose owners are the target audience of the advertisement. In addition, a rhythmic repetition is implemented with the help of the diminutive form киска and Whiskas nomen. It allows a quick memorization of the advertisement text.

2) Homonyms. In addition to onomatopoeia, advertising features homonymy as one of the widespread tactics of the language game at the phonetic level. N.V. Netyago defines homonymy as "two or more words with different meanings which are written and sounded equally... Homonymy is a lexical phenomenon of coincidence in pronunciation and spelling of different words that do not have a common meaning" (NETYAGO, 2016, p. 29). Homonymy differs from polysemy because a homonymous pair may differ both in spelling and pronunciation. 
It is worth noting that partial homonyms are divided into homophones, homoforms and homographs. To one degree or another, they all become the basis for the language game.

1. Homophones (phonetic homonyms):

Квас $\neg-$ не кола, пей Николу! (advertisement of kvass Nikola: Kvass, not Cola, drink Nikola! $)^{4}$.

An example of the use of phonetic homonyms is seen in advertisement of kvass Nikola. Lexical units (a common noun in a negative form and a proper noun) "not Cola" and "Nikola" are similar in pronunciation. The unit "not Cola" is phonetically reduced. In Russian transcription it is presented as follows: [n'i k'ol]. As a result, it turns to be really similar to the transcription of the word "Nikola": [n'ik'ol]. This advertisement uses a rhythmic repetition created with the help of homophones. The slogan is easy to memorize due to the language game and rhyme.

2. Homoforms (grammatical or morphological homonyms)

Будь мужиком, смени пол! ... А так же обои и двери (advertising of a furniture store: Be a man, change your gender! ... And also wallpaper and doors) ${ }^{5}$.

This advertisement successfully creates a comic effect. Here the word "пол" in the meaning of gender is homonymous to the noun "floor" in the singular accusative case. The phrase "Be a man, change your gender!" is built on an oxymoron, an ostensible selfcontradiction. In addition, the slogan itself is perceived as somewhat impudent and even defiant. In combination with the oxymoron, the homoform becomes a tool to attract consumer attention. The advertiser is clearly intended to recommend the client to make home improvements rather than convincinge him to change his gender. At the beginning the advertisement's author arouses the interest through the expression "to have a gender change". Afterwards the attention of consumers is shifted to a certain object by the use of a homoform.

It is obvious that the language game at the phonetic level is usually associated with oral texts. Despite the fact that only written texts were used and analyzed in the present study, for its entirety it seems necessary to consider the features of the language game in verbal advertising.

In addition to written advertising, there is verbal advertising, for example, radio advertising. When compiling written texts, it is important to take into account the phonetic aspect: how it will be read or pronounced in the mind. The advertisers commonly try to 
influence the target audience as efficiently and effectively as possible through all communication channels.

Nonce words (occasionalisms) are revealed at the lexical-morphological level.

One of the frequent types of the language game at the lexical level is a game based on nonce words. This term is defined in the Dictionary of Linguistic Terms in the following manner:

It is a brand-new word coined by a poet or writer according to unproductive word-formation models existing in the language. It is used exclusively in the given context as a lexical means of expressiveness or a language game. Nonce words are usually not wide distributed; they are not adopted by a language (ROZENTHAL, 1976, p. 543).

To understand nonce words in such cases, the recipient is clearly required to have a subtle linguistic sense. It should be observed that such tactics is often difficult to quickly understand. Since it can cause the opposite effect, its use in advertising is limited. The slogan of Snickers chocolate bar has been popular for several years and is considered successful:

Не тормози, сникерсни! (Don't stop, grab a Snickers) ${ }^{6}$

In the cited example, сникерсни is an occasional verb stemmed from the noun Snickers according to the Russian word-formation model. This nonce word has gradually come into general use due to popularity of the chocolate bar. It can be assumed that the success of the advertisement depends on the combination of the language game with the name of the advertised brand. For this reason, not only the Snickers advertisement attract attention with the help of an unusual imperative, it imperceptibly implants the name of the product in the mind of consumers.

\section{Summary}

The language game is generally used in various discourses considering its implementation at different levels of the language. In this regard, it is critical to provide insight into its types at each language level to understand successful tactics of the language game. This article demonstrates specific techniques used for producing creative and attractive advertisements. Particular emphasis is placed on the analysis of onomatopoeia and homonyms carried out at the phonetic level, and nonce words at the lexical-morphological level. Onomatopoeia evokes associations among the recipients by creating a connection between the 
sound and the brand name or the product itself. An important finding in the study is that the use of homonyms makes advertisements rhythmically memorable while nonce words influence on their uniqueness. Consequently, the effectiveness and efficiency of advertising is improved.

The aforementioned examples and the respective analysis prove that the use of the language game provides information richness of advertisements and can attract the attention of buyers which corresponds to the main advertising goal. Therefore, the present findings confirm that advertising is, to some extent, an ideal environment for fulfilling its influence and informational functions through the language game. The implementation of the language game in advertising has solid grounds for further research.

\section{Conclusions}

This article aimed to develop and analyze advertisements at some language levels with an emphasis on the use of language game. On the basis of the selected advertisements, reviewed cases of various creative language techniques and theoretical conclusions in the advertising discourse, it seems that the study goals have been achieved.

The limited knowledge in this issue determines the prospects of studying the language units that are used by copywriters for greater impact on the consumer. The present findings and conclusions might prove important in further research, including, as previously stated, studies of the language game in advertisements as part of other discourses, stylistic and grammatical features of advertising in various discourses.

ACKNOWLEDGEMENTS: The work is performed according to the Russian Government Program of Competitive Growth of Kazan Federal University.

\section{REFERENCES}

AGEEVA, J. Communicative Tactics of Persuasion in Sales (Lexical-Semantic Aspect). In: INTERNATIONAL MULTIDISCIPLINARY SCIENTIFIC CONFERENCE ON SOCIAL SCIENCES AND ARTS, 4., 2017, Bulgaria. Anais [...]. Bulgaria: SGEM, 2017. p. 629-636.

AGEEVA, J. Communicative Tactics of Persuasion in Sales (Lexical-Semantic Aspect). In: INTERNATIONAL MULTIDISCIPLINARY SCIENTIFIC CONFERENCE ON SOCIAL SCIENCES AND ARTS, 4., 2017, Bulgaria. Anais [...]. Bulgaria: SGEM, 2017. p. 629-636. 
AGEEVA, J.; YU, V. Functioning of Professional Vocabulary in New Business Discourse. In: INTERNATIONAL SCIENTIFIC CONFERENCE, 13., 2018. Current issues of the Russian language teaching. Anais [...]. 2018. p. 520-525.

GIMRANOVA, T. A.; KOLOSOVA, E. I.; SEMUSHINA, E. Y. Indirect tactics of speech influence in the political discourse, Iioab Journal, p. 40-43, 2018.

GRIDINA, T. A. Language game: stereotype and creativity. Yekaterinburg: Ural State Pedagogical University, 1996. 215 p.

GUZAEROVA, R. R.; BASTRIKOV, A. V. Miao Sun. Mediaspace as a Special Sphere of Production an Extra-Dystemic Vocabulary (on the example of Russian Feminitives with suffixes -ecc(a), -c(a)). Turismo-estudos e praticas, n. 2, p. 1-7, 2019.

ILYASOVA, S. V.; AMIRI, L. P. Language game in the communicative space of the media and advertising. M.: Flint, 2009.

LEBEDEVA, E. B. On clarification of the term" language game" in linguistics. 2014.

MIFTAKHOVA, A. N.; BOCHINA, T. G.; SERGEEVA, E. Gender interpretation of woman lexeme in internet discourse. Journal of Pharmacy Research, v. 11, n. 11, p. 1336-1340, 2017.

MIKHAYLOV, N. N. English for hospitality and tourism. Moscow: Akademia, 2011. 198 p.

NETYAGO, N. V. Lexicology of modern russian language: kick start for international students: [study guide]. Moscow: Ministry of Education and Science of the Russian Federation, Ural Federal University; Yekaterinburg: Publishing House of Ural University, 2016. $100 \mathrm{p}$.

ROZENTHAL, D. E. Dictionary of linguistic terms. In: ROZENTHAL, D. E.;

TELENKOVA, M. A. Teacher's resource book. 2. ed. rev. Moscow: «Prosvescheniye», 1976. $543 \mathrm{p}$.

SCHURINA; YU, V. Precedent-setting Elements in Structure of Small Comic Genres.

Russian Linguistic Annual Book, Krasnoyarsk, v. 1, n. 8, p. 77-84, 2006.

SHULEZHKOVA, S. G.; WALTER, H.; BOCHINA, T. G.; KOSTINA, P. M. Slogans appeared during the crimean spring in the political discourse of modern Russia. Issues of Cognitive Linguistics, v. 5, p. 358-361, 2017.

YAPPAROVA, V. N.; AGEEVA, J. V.; AGMANOVA, A. Y. Pre-election discourse as a special type of institutional discourse. Helix, v. 8, n. 1, p. 2324-2327, 2017.

YAPPAROVA, V. N.; BOCHINA, T. G.; SADYKOVA, I. A. Genre originality of the modern diplomatic discourse. Journal of Language and Literature, v. 7, n. 3, p. 195-198, 2016. 
YARTSEVA, V. N. Lingvisticheskiy entsiklopedicheskiy slovar'[Linguistic encyclopedic dictionary]. Moscow: Sovetskaya entsiklopediya Publ., 1990.

ZEMSKAYA, E. A.; KITAYGORODSKAYA, M.V.; ROZANOVA, N. N. Language Game. In: Conversational russian speech: phonetics. Morphology. Vocabulary. Gesticulation. Moscow: Nauka, 1983. p. 182-214.

\section{How to reference this article}

NIANZU, C.; AGEEVA, J. V.; YI, L. Advertising as a platform for language game. Rev. EntreLínguas, Araraquara, v. 7, n. esp. 1, p. 12-21, fev. 2021. e-ISSN: 2447-3529. DOI: https://doi.org/10.29051/el.v7iEsp1.14854

Submitted: $28 / 10 / 2020$

Required revisions: $19 / 12 / 2020$

Approved: $13 / 01 / 2021$

Published: 28/02/2021 